\title{
PENGARUH CORPORATE SOCIAL RESPONSIBILITY TERHADAP AGRESIVITAS PAJAK DENGAN INSENTIF PAJAK SEBAGAI PEMODERASI (STUDI PADA PERUSAHAAN PERTAMBANGAN YANG TERDAFTAR DI BEI)
}

\author{
Kholid Hidayat, Arles P. Ompusunggu, H. Suratno \\ Magister Akuntansi Universitas Pancasila, Jl. Srengseng Sawah, Jakarta 12640, Indonesia \\ E-mail: kholidhidayat@gmail.com
}

\begin{abstract}
This study is aimed to examine the effect of Corporate Social Responsibility (CSR) to tax aggresiveness with tax incentive as a moderator. The study population used was the mining companies listed in Indonesia Stock Exchange with sample consisted of 34 companies which were obtained by purposive sampling method between 2011 and 2015. This study used CSR (as independent variable), tax aggressiveness (as dependent variable) and tax incentive (as moderating variable). To control the effect of CSR to tax aggressiveness, this study used variable controls namely leverage, size, Return On Assets (ROA), capital intensity and inventory intensity. While dependent variable, tax aggressiveness, was measured by using a proxy: Effective Tax Rate (ETR). CSR has been carried out by using Corporate Social Responsibility Index (CSRI) and data analysis technique has been done by using Moderated Regression Analysis (MRA). In addition the data was processed by using SPSS 22. The result showed that CSR has negative influence to tax agressiveness. The higher the level of corporation's CSR disclosure, the lower is the level of tax aggressiveness.Tax incentives was proven and capable to strenghthen the relation between CSR and tax aggressivenes. CSR simultantly tested with the control variables showed similar result. It has negative influence. The higher the level of corporation's CSR disclosure, the lower is the level of tax aggressiveness.
\end{abstract}

Keywords: CSR, Tax Aggressivenes, Tax Incentives

\section{Pendahuluan}

Penghindaran pajak agresif (agresivitas pajak) dilakukan dengan berbagai skema transaksi keuangan, baik yang legal maupun illegal berdampak mempengaruhi penurunan penerimaan negara yang digunakan untuk tujuan peningkatan kesejahteraan masyarakat. Dengan sistem pemungutan pajak di Indonesia berdasarkan self assessment (wajib pajak menghitung, menyetor dan melaporkan sendiri pajak yang terutang) dengan tulang punggung kepatuhan sukarela (voluntary compliance), maka seharusnya wajib pajak menjalankan kewajiban membayar pajak dengan benar. Namun demikian, dari sudut pandang logika bisnis, mereka menganggap bahwa pajak adalah biaya pelaksanaan usaha (cost of doing business). Model pemikiran ini akan menyebabkan perusahaan perusahaan berusaha mengeluarkan beban pajak seefisien mungkin, perusahaan akan melakukan perencanaan pajak (tax planning) yang bertujuan untuk meminimalkan pajak terutang untuk memaksimalkan laba sebelum pajak yang optimal. (Mangoting, 1999). Strategi manajerial untuk meminimalkan pajak melalui tindakan agresivitas pajak menjadi fitur yang umum dari lanskap perusahaan di seluruh dunia (Lanis dan Richardson, 2012).

Perusahaan selama ini beranggapan memiliki dua beban yang sama untuk kepentingan kesejahteraan masyarakat yaitu beban pajak dan beban Corporate Social Responcibility (CSR). Agar perusahaan tidak memiliki dua beban maka perusahaan mulai mencari cara untuk meminimalkan pajak perusahaan melalui kegiatan agresivitas pajak. Perusahaan lebih mempertimbangkan pengeluaran dana untuk CSR yang dapat mengurangi laba kena pajak. Seharusnya perusahaan tidak melakukan strategic tax behaviour (perilaku penghindaran pajak) yang

JIAFE (Jurnal Ilmiah Akuntansi Fakultas Ekonomi)

Volume 2 No. 2 Tahun 2016, Hal. 39-58 
merusak hubungan konstitutif antara negara dan perusahaan (Avi-Yonnah, 2008).

Sesuai data empiris, pada tahun 2015 tax ratio Indonesia hanya mencapai 12,7 persen (dibanding dengan negara ASEAN, tax ratio tersebut berada di bawah rata-rata tax ratio negara ASEAN). Hal ini mencerminkan adanya output kinerja ekonomi yang tercermin dalam PDB belum dikenakan pajak.
Rendahnya tax ratio Indonesia dibanding negara ASEAN telah mendorong Direktorat Jenderal Pajak (DJP) dan Badan Kebijakan Fiskal (BKF) untuk membuat aturan (tax policy) dan usaha lainnya (tax effort) yang mampu meningkatkan kepatuhan wajib pajak dengan memperluas basis pemajakan (baik jumlah wajib pajak maupun peraturan perundang-undangan yang memperluas objek pemajakan).

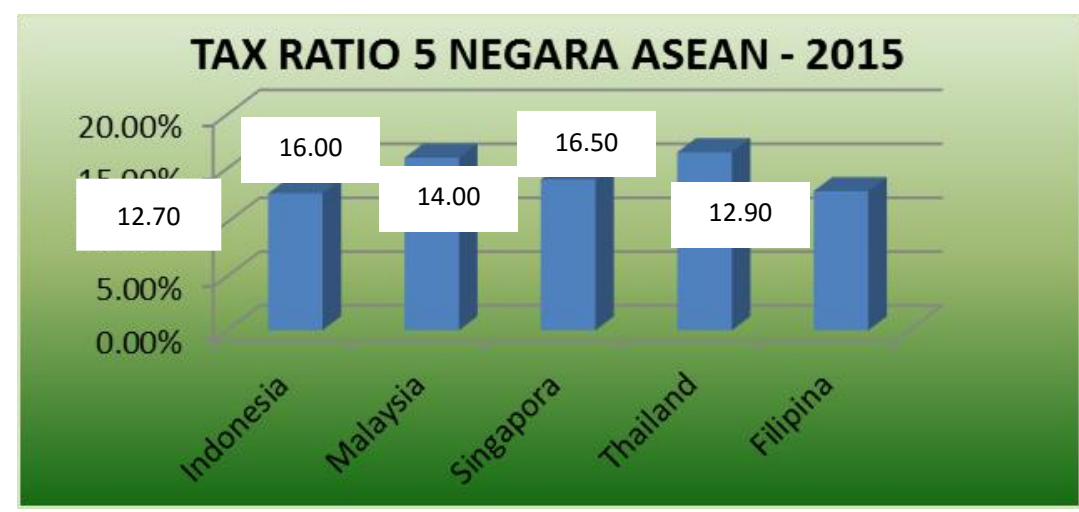

Gambar 1

Tax Ratio 5 Negara ASEAN Tahun 2015

Fenomena agresivitas pajak banyak terjadi di perusahaan penanaman modal asing (Brodjonegoro, 2016). Fenomena ini juga terjadi pada perusahaan pertambangan. Hal ini dapat dilihat adanya ketetapan pajak hasil pemeriksaan DJP dan rendahnya tax ratio sektor pertambangan. Pada tahun 2010 beberapa perusahaan pertambangan mempunyai tunggakan pajak dari hasil pemeriksaan Direktorat Jenderal Pajak (DJP) masing-masing Rp1,5 triliun untuk PT. Kaltim Prima Coal, Rp376 miliar untuk PT. Bumi Resources, dan US\$27,5 juta untuk PT. Arutmin (Hardianti, 2014). Disamping itu, data tax ratio sektor pertambangan tahun 2014 menunjukkan rasio sebesar 9,4\% (Saputra, 2015). Nilai tersebut menunjukkan angka di bawah tax ratio secara nasional tahun 2014, yaitu sebesar 10,88 \%. Fenomena ketetapan pajak dari DJP dan rendahnya tax ratio sektor pertambangan di bawah tax ratio secara nasional ini mengindikasikan terjadinya tindakan agresivitas pajak di sektor pertambangan.
Organization for Economic Co-operation and Developmnet (OECD) mendeskripsikan tax avoidance adalah usaha wajib pajak mengurangi pajak terutang, meskipun upaya ini bisa jadi tidak melanggar hukum (the letter of the (aw), namun sebenarnya bertentangan dengan tujuan dibuatnya peraturan perundang-undangan perpajakan (the spirit of the law). Justice Reddy (dalam kasus McDowell \& Co Versus CTO di Amerika Serikat) merumuskan tax avoidance sebagai seni menghindari pajak tanpa melanggar hukum (Prastowo, 2016). Walaupun secara literal tidak ada hukum yang dilanggar, semua pihak sepakat bahwa agresivitas pajak atau penghindaran pajak merupakan sesuatu yang secara praktik tidak dapat diterima. Hal ini dikarenakan penghindaran pajak secara langsung berdampak pada tergerusnya basis pajak, yang mengakibatkan berkurangnya penerimaan pajak yang dibutuhkan oleh negara. Menurut Lanis dan Richardson (2013) pandangan masyarakat mengenai perusahaan yang melakukan tindakan agresivitas pajak dianggap telah membentuk suatu kegiatan 
yang tidak bertanggung jawab secara sosial dan tidak sah. Dalam Undang-Undang RI No. 40 tahun 2007 pasal 74 mengenai tanggung jawab sosial dan lingkungan, tertulis bahwa "Perseroan yang menjalankan kegiatan usahanya di bidang dan/atau berkaitan dengan sumberdaya alam wajib melaksanakan tanggung jawab sosial dan lingkungan". Sebutan lain bagi tanggung jawab perusahaan adalah Corporate Social Responsibility (CSR). Hubungan CSR dengan agresivitas pajak dapat dijelaskan bahwa CSR merupakan bentuk tanggung jawab perusahaan kepada semua stakeholder-nya. Dan pajak merupakan salah satu bentuk tanggung jawab sosial perusahaan kepada stakeholder-nya melalui pemerintah. Dengan demikian, perusahaan yang terlibat penghindaran pajak adalah perusahaan yang tidak bertanggung jawab sosial (Lanis dan Richardson, 2012). Sehingga keputusan perusahaan untuk mengurangi tingkat pajaknya atau melakukan penghindaran pajak juga dipengaruhi oleh sikapnya terhadap CSR.

Pengungkapan CSR adalah proses pengkomunikasian efek-efek sosial dan lingkungan atas tindakan ekonomi perusahaan pada kelompok-kelompok tertentu dalam masyarakat dan pada masyarakat secara keseluruhan (Gray et. al., 1987 dalam Rosmasita, 2007). Terdapat ketentuan dalam Pasal 66 ayat 2c UU No. 40 tahun 2007, yang menyatakan bahwa semua perseroan wajib untuk melaporkan pelaksanaan tanggung jawab sosial dan lingkungan dalam laporan tahunan. Dalam pandangan bisnis bahwa pembayaran CSR dan pajak adalah cost of doing business yang mempunyai tujuan yang sama, yaitu untuk memenuhi kesejahteraan masyarakat melalui penyediaan barang dan jasa untuk masyarakat (public goods and services), maka perusahaan akan merencanakan CSR dan pajak seefisien mungkin dan dimungkinkan untuk memilih salah satu dari keduanya. Watson (2011) menyatakan bahwa pengungkapan CSR yang rendah dianggap sebagai perusahaan yang tidak bertanggung jawab secara sosial. Perusahaan yang mengungkap CSR rendah mampu melakukan strategi pajak yang lebih agresif dibanding perusahaan dengan tingkat CSR yang tinggi. Sementara itu, perusahaan yang melakukan pengungkapan CSR yang tinggi teridentifikasi melakukan kepatuhan pajak yang tinggi atau tingkat penghindaran pajaknya relatih lebih rendah.

Penelitian akuntansi terkait CSR terhadap agresivitas pajak telah banyak dilakukan, seperti Lanis dan Richardson, 2012; Huseynov dan Klam, 2012 yang dalam penelitiannya membahas hubungan antara pengungkapan CSR dengan agresivitas pajak dengan proksi ETR (Effective Tax Rates). Penelitian lainnya dilakukan oleh Ratmono, Winarti dan Sagala (2015). Hasil penelitian menyatakan bahwa semakin tinggi tingkat pengungkapan CSR dari suatu perusahaan, semakin rendah tingkat agresivitas pajak perusahaan tersebut. CSR berpengaruh negatif terhadap agresivitas pajak. Penelitian lain terkait pengaruh CSR terhadap agresivitas pajak atau penghindaran pajak menunjukkan adanya hasil yang berbeda. Preuss (2010) dan Sikka (2010) berpendapat bahwa beberapa perusahaan yang mengklaim melakukan CSR tetap melakukan penghindaran pajak. Dengan demikian, semakin tinggi pengungkapan CSR, semakin tinggi pula penghindaran pajak yang dilakukan. Dalam konteks Indonesia belum banyak penelitian yang dilakukan terkait CSR dan agresivitas pajak, khususnya jika dihubungkan dengan insentif pajak atas CSR sesuai Undang-Undang No. 36 tahun 2008 tentang Perubahan Keempat Undang-Undang Pajak Penghasilan (UU PPh) dan Pemerintah Nomor 93 tahun 2010 serta Peraturan Menteri Keuangan Nomor 76 tahun 2011. Yaitu diberikannya insentif pajak atas pengeluaran CSR berupa tax deduction (diperbolehkannya pengeluaran perusahaan terkait CSR dalam menghitung Penghasilan Kena Pajak), sehingga Pajak Penghasilan (PPh) yang terutang menjadi lebih kecil. Dengan pengurangan pajak tersebut, insentif pajak diduga mempengaruhi hubungan CSR dengan agresivitas pajak.

Adanya indikasi praktik penghindaran pajak di sektor perusahaan PMA, rendahnya tax ratio Indonesia dibanding dengan

JIAFE (Jurnal Ilmiah Akuntansi Fakultas Ekonomi)

Volume 2 No. 2 Tahun 2016, Hal. 39-58 
beberapa negara ASEAN dan rendahnya tax ratio sektor pertambangan dibanding tax ratio secara nasional serta hasil pemeriksaan pajak terhadap beberapa perusahaan pertambangan yang menyebabkan ketetapan pajak kurang bayar merupakan fenomena yang menggambarkan adanya upaya penghindaran pajak (Negoro, 2013). Simptom tersebut merupakan fenomena menarik untuk dilakukan penelitian.Hal ini disebabkan penghindaran pajak yang dilakukan perusahaan menyebabkan penerimaan negara untuk membiayai kesejahteraan masyarakat tidak tercapai.

Ditinjau dari pandangan teori psikologi, yaitu teori perilaku atau theory planned of behavior dengan motivasi sikap atau behavioral beliefs, seharusnya perusahaan mempunyai kesadaran untuk membayar pajak dengan benar karena pentingnya pajak untuk pembiayaan pembangunan. Sementara itu dalam pandangan teori sosiologi, penghindaran pajak atau agresivitas pajak bertentangan dengan teori pemangku kepentingan (stakeholder theory). Perusahaan seharusnya beraktivitas tidak hanya untuk kepentingan pemilik saham, melainkan juga bagi semua pemangku kepentingan (stakeholders), termasuk pemerintah dengan cara ketaatan membayar pajak, dan tidak melakukan penghindaran pajak.

Adanya fenomena dan research gap di atas mendorong penulis untuk melakukan penelitian dengan topik penghindaran pajak (agresivitas pajak) dengan proksi Effective Taxes Rate (ETR). ETR merupakan efektifitas pembayaran pajak perusahaan yang merefleksikan besarnya penghindaran pajak atas perhitungan tarif pajak terhadap laba perusahaan. ETR merepresentasikan berapa persentase perusahaan membayar pajak sebenarnya terhadap laba komersial. Semakin rendah nilai ETR maka semakin tinggi kecenderungan perusahaan melakukan agresivitas pajak.

Penelitian ini dilakukan dengan tujuan untuk menginvestigasi dan menjelaskan secara empiris pengaruh pengungkapan CSR terhadap agresivitas pajak serta pengaruh insentif pajak terhadap hubungan keduanya. Insentif pajak tersebut adalah tax deduction (pengurangan pajak) atas beban CSR sesuai ketentuan pasal 6 ayat 1 UU PPh jo PP 93 tahun 2010 atau pelaksanaan ketentuan Kontrak Karya (KK) dan Perjanjian Kerjasama Pengusahaan Pertambangan Batubara (PKP2B).

\section{Telaah Teori dan Pengembangan Hipotesis Theory of Planned Behavior (TPB)}

Theory of Planned Behavior (TPB) merupakan perluasan dari Theory of Reasoned Action (TRA). Dalam TRA dijelaskan bahwa niat seseorang terhadap perilaku dibentuk oleh dua faktor utama yaitu attitude toward the behavior dan subjective norms (Fishbein dan Ajzen, 1975), sedangkan dalam TPB ditambahkan satu faktor lagi yaitu perceived behavioral control (Ajzen, 1991). TPB sangat sesuai digunakan untuk menjelaskan berbagai perilaku. Sebagaimana dikatakan oleh Ajzen (1991) bahwa TPB is suitable to explain any behavior which requires planning, such as entrepreneurship (TPB cocok untuk menjelaskan perilaku apapun yang memerlukan perencanaan, seperti penghindaran pajak yang dilakukan melalui tax planning). Wajib pajak yang sadar pajak, akan memiliki keyakinan mengenai pentingnya membayar pajak untuk pembiayaan pembangunan (attitude atau behavioral beliefs). Sebaliknya keyakinan yang rendah akan pentingnya membayar pajak akan menyebabkan rendahnya kesadaran untuk membayar pajak melalui perilaku penghindaran pajak.

\section{Stakeholder Theory}

Stakeholder theory (teori pemangku kepentingan) relevan untuk menjelaskan tindakan agresivitas pajak dan CSR. Edward Feeman (1984) dalam stakeholder theory mengatakan bahwa kinerja sebuah organisasi dipengaruhi oleh semua stakeholder organisasi, oleh karena itu merupakan tanggung jawab manajerial untuk memberikan benefit kepada semua stakeholder yang berpengaruh terhadap kinerja organisasi. Pemerintah sebagai regulator, merupakan 
salah satu stakeholder perusahaan. Oleh karena itu perusahaan harus memperhatikan kepentingan pemerintah. Salah satunya adalah dengan cara mengikuti semua peraturan yang dibuat oleh pemerintah, ketaatan membayar pajak, dan tidak melakukan penghindaran pajak.

\section{Teori Pertukaran Sosial}

Teori pertukaran sosial merupakan teori yang digunakan untuk menjelaskan pengaruh insentif pajak terhadap hubungan CSR dan agresivitas pajak. Asumsi dasar teori ini adalah setiap individu secara sukarela memasuki dan tinggal dalam hubungan social hanya selama hubungan tersebut cukup memuaskan jika ditinjau dari sisi biaya dan benefit (Thibaut dan Kelley, 1959).Teori ini menjelaskan bahwa suatu tindakan akan terjadi jika menghasilkan benefit timbal balik (reciprocal) bagi kedua belah pihak. Demikian juga sebaliknya, jika suatu tindakan tidak memberikan benefit, maka tindakan tersebut cenderung akan ditinggalkan.

\section{Corporate Social Responsibility (CSR), Insentif Pajak dan Agresivitas Pajak}

Kottler(2005) menjelaskan bahwa CSR

merupakan komitmen perusahaan untuk meningkatkan kualitas hidup masyarakat melalui tingkat-tingkat bisnisnya. CSR merupakan bentuk perhatian bisnis untuk menjamin agar praktek usahanya memenuhi kriteria tanggung jawab pada semua pemangku kepentingan. Sehingga perusahaan tidak hanya berorientasi laba semata, tetapi juga berorientasi pada lingkungan dan sosial di sekitar perusahaan. Hlaing (2012) mendefinisikan agresivitas pajak sebagai kegiatan perencanaan pajak semua perusahaan yang terlibat dalam usaha mengurangi tingkat pajak yang efektif. Tindakan agresivitas pajak ini tidak hanya berasal dari ketidakpatuhan terhadap peraturan perpajakan namun dapat juga berasal dari aktivitas penghematan yang sesuai dengan peraturan yang berlaku sehingga sering kali agresivitas pajak disebut juga sebagai tax sheltering atau tax avoidance. Effendi (2010) menyatakan pemerintah telah memberikan insentif pajak terkait CSR. Yaitu diperbolehkannya dana CSR sebagai pengurang Penghasilan Kena Pajak (Ph KP) atau tax base. Kebijakan ini akan mengakibatkan Ph KP menjadi lebih kecil bagi organisasi yang melakukan aktivitas CSR, sehingga besaran pajaknya pun akan menjadi lebih kecil. Insentif pajak diatur pada pasal 6 ayat (1) UU PPh dan PP Nomor 93 tahun 2010.

\section{Pengembangan Hipotesis}

Hubungan CSR dengan agresivitas pajak dapat dijelaskan bahwa CSR merupakan bentuk tanggung jawab perusahaan kepada semua stakeholder-nya. Pajak merupakan salah satu bentuk tanggung jawab sosial perusahaan kepada stakeholder-nya melalui pemerintah. Dengan demikian, perusahaan yang terlibat penghindaran pajak adalah perusahaan yang tidak bertanggung jawab social (Lanis dan Richardson, 2012). Sehingga keputusan perusahaan untuk mengurangi tingkat pajaknya atau melakukan penghindaran pajak juga dipengaruhi oleh sikapnya terhadap CSR. Dalam penelitian terdahulu yang dilakukan Lanis dan Richardson (2012), Huseynov dan Klam (2012) dalam penelitiannya membahas hubungan antara pengungkapan CSR dengan agresivitas pajak. Hasil penelitian menunjukkan bahwa semakin tinggi tingkat pengungkapan CSR dari suatu perusahaan, semakin rendah tingkat agresivitas pajak perusahaan tersebut.

\section{H1: CSR berpengaruh negatif terhadap agresivitas pajak}

Dengan adanya ketentuan pasal 6 ayat 1 huruf $\mathrm{i}, \mathrm{j}, \mathrm{k}$, I dan $\mathrm{m}$ UU PPh serta PPNo.93 tahun 2010 yang membolehkan CSR sebagai biaya secara fiskal (deductible expenses), maka akan terjadi penurunan tingkat penghindaran pajak atau agresivitas pajak. Dengan diperbolehkannya CSR tertentu deductible expenses, maka perusahaan akan memperoleh tax saving (berupa pengurangan beban pajak) dan tidak perlu lagi menyiasati pengeluaran aktivitas CSRnya ke pos biaya yang lain yang

JIAFE (Jurnal Ilmiah Akuntansi Fakultas Ekonomi)

Volume 2 No. 2 Tahun 2016, Hal. 39-58 
merupakan tindakan penghindaran pajak terdahulu, dimana Corporate Social secara illegal (Amna, 2010).

Responsibility (CSR) diduga memiliki pengaruh negatif terhadap agresivitas pajak

H2: Insentif pajak berpengaruh positif (Lanis and Richardson, 2011 dan Ratmono dan (memperkuat) hubungan CSR agresivitas pajak

dengan Sagala (2015). Semakin tinggi pengungakapan CSR maka semakin rendah agresivitas pajak. Sementara itu insentif pajak berpengaruh

\section{Rerangka Pemikiran Teoritis}

Penelitian ini merupakan pengembangan signifikan terhadap hubungan CSR dengan agresivitas pajak (Amna, 2010).

dari beberapa konsep teori dan penelitian

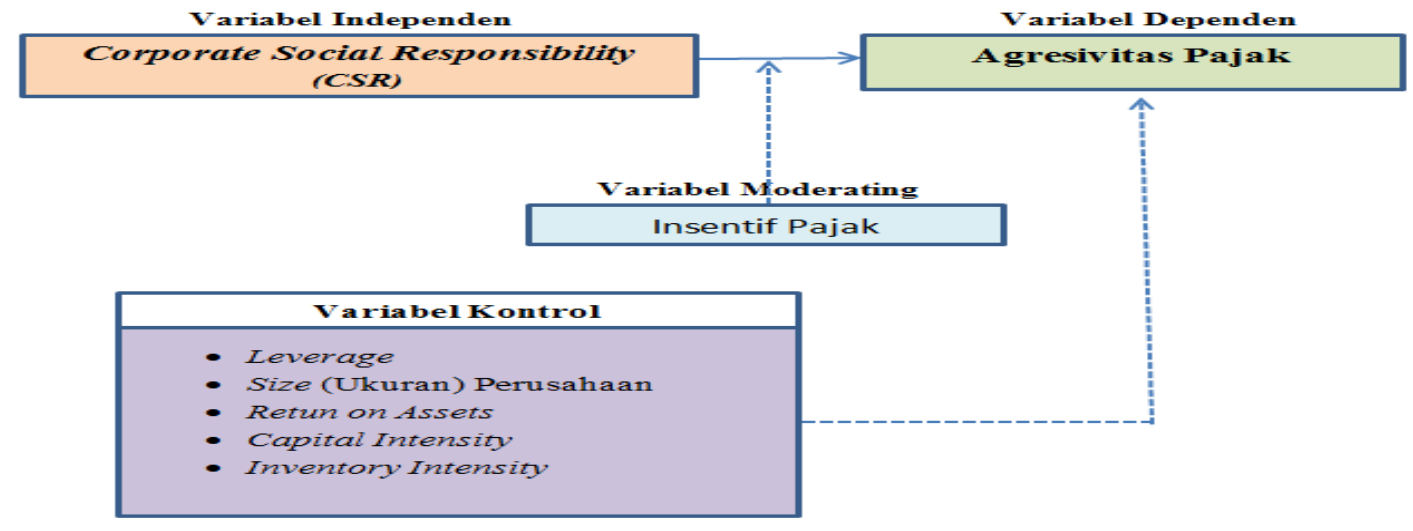

Gambar 2

Rerangka Pemikiran Teoritis

\section{Metode Penelitian}

Populasi dan Sampel

Populasi dalam penelitian ini adalah 41 perusahaan pertambangan yang terdaftar pada Bursa Efek Indonesia (BEI) pada periode tahun 2011 s.d 2015. Dari jumlah populasi tersebut, 34 perusahaan dijadikan sampel penelitian dengan menggunakan metode purposive sampling. Yaitu perusahaan pertambangan yang memenuhi kriteria konsistensi dalam menerbitkan annual report selama 2011-2015. Sebanyak 7 perusahaan tidak dijadikan sampel penelitian karena perusahaan tersebut delisting dan suspend (tidak atau belum menerbitkan annual report yang konsisten selama 2011-2015). Untuk penelitian korelasional dalam desain penelitian kausalitas, jumlah sampel tersebut telah memenuhi syarat kecukupan sampel (Gay dan Diehl, 1992).

\section{Definisi Operasionalisasi Variabel Variabel Dependen}

Variabel yang akan digunakan dalam penelitian ini adalah agresivitas pajak. Khurana dan Moser (2009) mendefinisikan agresivitas pajak sebagai tax planning perusahaan melalui aktivitas penghindaran pajak (tax avoidance atau tax sheltering). Adapun yang menjadi proksi agresivitas pajak adalah Effective Tax Rates (ETR) yang menggambarkan persentase total beban pajak penghasilan yang dibayarkan perusahaan dari seluruh total laba sebelum pajak. Lanis dan Richardson (2012) menyatakan ETR merupakan pengukuran agresvitas yang sering digunakan dalam penelitian. Nilai ETR dianggap dapat merefleksikan perbedaan tetap (permanent different) antara perhitungan laba akuntansi dengan laba fiskal (Frank et al. 2009). ETR mencerminkan besarnya beban pajak kini yang terutang oleh perusahaan dari laba komersial yang diperoleh perusahaan selama periode berjalan.

ETR menyediakan informasi mengenai efek kumulatif dari insentif pajak serta perubahan tarif pajak yang terjadi dalam suatu 
perusahaan. Proksi ETR dinilai menjadi indikator adanya agresivitas pajak apabila memiliki ETR yang mendekati nol; diformulasikan pembagian beban pajak penghasilan dengan laba sebelum pajak dikalikan 100 persen. Semakin tinggi nilai ETR maka semakin rendah tingkat agresivitas pajak.

\section{Variabel Independen}

Variabel independen penelitian ini adalah Corporate Social Responsibility (CSR). Pengungkapan CSR adalah provisi atas informasi terkait aspek sumberdaya manusia, produk dan jasa, keterlibatan perusahaan dalam proyek kemasyarakatan, termasuk aktivitas sosial dan aktivitas terkait lingkungan lainnya (Esa dan Ghazali , 2010).

Tingkat pengungkapan Corporate Social Responsibility (CSR) pada laporan tahunan (annual report) perusahaan yang yang akan dinilai dengan membandingkan jumlah pengungkapan yang dilakukan perusahaan. pengukuran kemudian dilakukan berdasarkan indeks pengungkapan masing-masing perusahaan yang dihitung melalui jumlah item yang sesungguhnya diungkapkan perusahaan dengan jumlah semua item yang mungkin diungkapkan (Corporate Social Responsibility Disclosure Index Perusahaan) atau disingkat CSRDI, yang diformulasikan dengan membagi jumlah item pengungkapan CSR yang dipenuhi dengan jumlah semua item pengungkapan CSR (79 item indikator pengungkapan CSR menurut GRI 3.0).

\section{Variabel Moderating}

Variabel moderating adalah variabel yang memperkuat atau memperlemah hubungan langsung antara variabel independen dengan variabel dependen (Indriantoro dan Supomo, 2002). Dalam penelitian ini, yang menjadi variabel moderating adalah insentif pajak dan berfungsi sebagai variabel moderating murni (pure moderating). Sehingga insentif pajak tidak berfungsi sebagai variabel independen (Ghozali, 2013). Pada saat syarat pembebanan CSR secara juridis fiskal terpenuhi, maka perusahaan dapat membebankan CSR secara fiskal. Dengan demikian perusahaan telah memperoleh insentif pajak (tax deduction). Sementara itu jika syarat pembebanan CSR secara fiskal tidak terpenuhi, maka perusahaan tidak memperoleh insentif pajak. Dengan demikian pengukuran insentif pajak ini bersifat kategorik (kualitatif) sesuai dasar juridis fiskal. Pada penelitian ini, insentif pajak dihitung dengan variabel dummy; kategori 1 untuk untuk perusahaan yang memperoleh insentif pajak (membebankan CSR secara fiskal) dan kategori 0 untuk perusahaan yang tidak memperoleh insentif pajak (tidak membebankan CSR secara fiskal).

\section{Variabel Kontrol}

Untuk mengendalikan agar pengaruh variabel independen (CSR) terhadap dependen (agresivitas pajak) tidak dipengaruhi faktor lain yang tidak diteliti dan untuk mengendalikan dampak variabel moderating (insentif pajak), maka penelitian ini menggunakan lima variabel kontrol yakni leverage (DER), size (ukuran perusahaan), return on assets (profitabilitas), capital intensity dan inventory intensity. Penggunaan variabel kontrol ini akan memperkuat model penelitian dengan penjelasan sebagai berikut.

\section{Leverage (DER)}

Rasio leverage merupakan proporsi total hutang terhadap ekuitas pemegang saham. Rasio tersebut digunakan untuk memberikan gambaran mengenai struktur modal yang dimiliki perusahaan, sehingga dapat dilihat tingkat resiko tak tertagihnya suatu utang (Purnasiwi, 2011). Untuk mengukur tingkat leverage adalah debt to equity ratio (DER). Leverage dirumuskan dengan rasio membagi total libilities dengan equity.

\section{Size}

Size atau ukuran perusahaan diartikan sebagai sebuah skala dimana perusahaan dapat dikategorikan besar dan kecil. Pada penelitian ini ukuran perusahaan dilambangkan dengan log natural total asset (Ln). 
3. Return on Assets (ROA)

ROA merupakan rasio profitabilitas untuk mengukur kemampuan perusahaan menghasilkan keuntungan dari aktivitas bisnisnya. ROA diperoleh dari pembangian antara net income dengan total asetnya.

\section{Capital Intensity}

Capital intensity atau intensitas modal menggambarkan seberapa besar kekayaan perusahaan yang diinvestasikan dalam bentuk aset tetap. Capital intensity menurut Lanis dan Richardson (2012) dihitung dengan membagi total net fixed assets dengan total assets.

5. Inventory Intensity

Inventory intensity atau bisa disebut juga dengan intensitas persediaan merupakan salah satu komponen penyusun komposisi aktiva. Inventory intensity memberi gambaran akan jumlah persediaan perusahaan yang dibutuhkan perusahaan untuk beroperasi yang diukur dengan membandingkan antara total persediaan dengan total aset yang dimiliki perusahaan.

Metode yang dipakai dalam analisis variabel-variabel dalam penelitian ini adalah dengan menggunakan regresi linier berganda yang dimoderasi (Multiple Regression Analysis (MRA).

Model yang digunakan dalam penelitian ini adalah :

$\mathrm{ETR}=\alpha+\beta 1 \mathrm{CSR}+\varepsilon$

ETR $=\alpha+\beta 1$ CSR $+\beta 1$ CSR $*$ TI $+\varepsilon$

ETR $=\alpha+\beta 1$ CSR $+\beta 2$ CSR $*$ TI $+\beta 2$ DER $+\beta 3$ Size

$+\beta 4$ ROA $+\beta 5$ Caplnt $+\beta 6$ InvInt $+\varepsilon \quad$....3)

Keterangan :

$\mathrm{ETR}=$ effecitive tax rate

$\mathrm{CSR}=$ Corporate social responsibility

$\mathrm{TI}=$ Tax incentive

CSR $* \mathrm{TI}=$ interaksi antara CSR dan TI

$\mathrm{DER}=$ Leverage perusahaan I pada periode $\mathrm{t}$

Size $=$ Ln total asset

ROA = Return on asset perusahaan I pada periode $\mathrm{t}$

Caplnt = Capital intensity

InvInt = Inventory intensity

$\alpha \quad=$ Konstanta

$\beta_{1}-\beta_{6}=$ Koefisien regresi

$\varepsilon \quad=$ Koefisien error dalam model

Dari penelitian ini diharapkan akan menghasilkan suatu gambaran deskriptif mengenai hubungan antara CSR terhadap ETR dan interaksi CSR dengan TI terhadap ETR.

\section{Asumsi Klasik}

\section{Gambar 3}

Hasil Uji Normalitas P-Plot

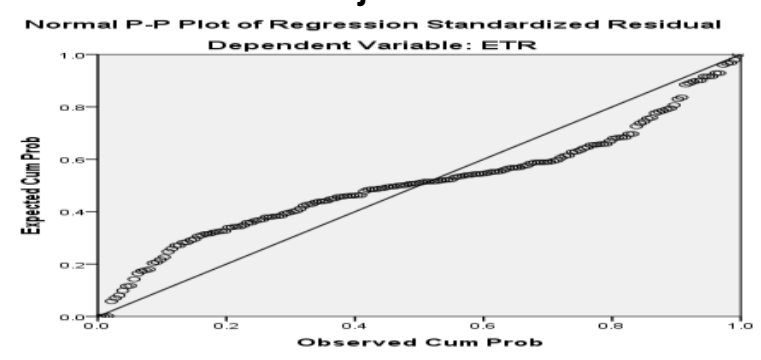

Pada output SPSS versi 22.0, P-P plot of regression data terlihat titik-titik cenderung lurus mengikuti garis diagonal, maka data dapat disimpulkan bahwa data terdistribusi normal atau memenuhi asumsi normalitas. 
Tabel 2

Hasil Uji Multikolinearitas

\begin{tabular}{|ll|r|r|}
\hline \multirow{2}{*}{ Model } & \multicolumn{2}{c|}{ Collinearity Statistics } \\
\cline { 2 - 4 } & (Constant) & & \multicolumn{1}{c|}{ Volerance } \\
\hline CSR & .173 & 5.788 \\
TI & .122 & 8.176 \\
CSR $*$ TI & .169 & 9.446 \\
DER & .831 & 1.204 \\
SIZE & .810 & 1.234 \\
ROA & .791 & 1.264 \\
C-INCT & .915 & 1.093 \\
IINV-INCT & .816 & 1.225 \\
\hline
\end{tabular}

Dependent Variable: ETR

Berdasarkan tabel di atas diketahui bahwa semua variabel bebas mempunyai nilai tolerance $>0.1$ dan VIF $<10$. Hal ini disimpulkan bahwa variabel independen tidak memiliki masalah multikolinearitas.
Uji Heteroskedastisitas dilakukan dengan scatter plot, yang menunjukkan tidak terdapat pola yang jelas, serta residual menyebar di atas angka 0 pada sumbu $Y$, maka tidak terjadi heteroskedastisitas, yang ditunjukkan pada gambar di bawah ini.

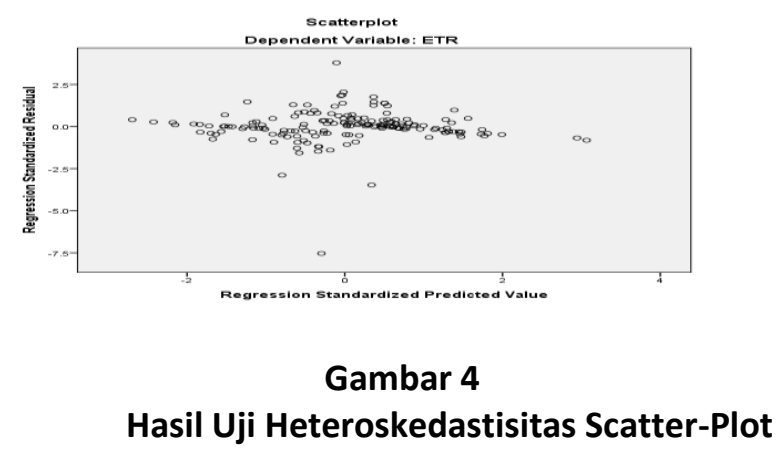

Berdasarkan olah data menggunakan SPSS, hasil uji autokorelasi dapat dilihat pada tabel di bawah ini.

Tabel 3

Hasil Uji Autokorelasi

\begin{tabular}{|c|c|}
\hline Model & Durbin-Watson \\
\hline 1 & 2.143 \\
\hline
\end{tabular}

a. Predictors: (Constant), CSR, CSRTI,SIZE, DER, ROA, C-INT, INV-INCT

b. Dependent Variable: ETR

Sumber : Data Bursa Efek Indonesia yang diolah 
Dari hasil output tabel 3 di atas, dapat dilihat bahwa nilai Durbin-Watson yang dihasilkan dari model regresi adalah 2,143. Sedangkan dari tabel DW dengan siginifikansi $\alpha$ 0,05, jumlah data n 170 dan k adalah 7, diperoleh nilai $\mathrm{dL}$ sebesar 1,6553 dan dU sebesar 1,8341. Nilai 4-dL sebesar 2,3447 dan nilai 4-dU sebesar 2,1659. Dengan demikian dapat disimpulkan bahwa nilai dU< DW < 4-du atau 1,8341<2,143<2,1659, maka hasilnya dapat disimpulkan tidak terjadi autokorelasi.

\section{Hasil Penelitian dan Pembahasan}

Hasil penelitian

Tabel 4.

Statistik Deskriptif

\begin{tabular}{lrrrrr}
\hline & N & \multicolumn{1}{c}{ Minimum } & Maximum & Mean & Std. Deviation \\
\hline ETR & 170 & -2.8073 & 1.6570 & .1869 & .40369 \\
CSR & 170 & .2152 & 1.0000 & .5894 & .22012 \\
TI & 170 & .0000 & 1.0000 & .8100 & .39700 \\
CSRTI & 170 & .0000 & 1.0000 & .4847 & .31031 \\
DER & 170 & .0134 & 3.5513 & .4995 & .34079 \\
SIZE & 170 & 6.7527 & 7.3248 & 7.0586 & .15570 \\
ROA & 170 & -.6012 & .7214 & .0676 & .16183 \\
CAPT-INT & 170 & .0000 & 1.2646 & .2758 & .19778 \\
INV-INT & 170 & .0000 & .5497 & .0743 & .09461 \\
Valid N (listwise) & 170 & & & &
\end{tabular}

Berdasarkan tabel 4di atas dapat dilihat bahwa selama periode penelitian, agresivitas pajak yang diproksikan dengan ETR dari 34 perusahaan industri pertambangan yang terdaftar di BEI tahun 2011 sampai 2015 minimum $-2,8073$ dan maksimum 1,6570 . Nilai rata-rata sebesar 0,1869 dan standar deviasi sebesar 0,40369. Berdasarkan nilai rata-rata ETR sebesar 0,1869 (atau 18,69 \%) lebih rendah dibanding tarif PPh WP Badan sesuai pasal 17 UU PPh, yaitu sebesar $25 \%$.

Tabel 5

Hasil Koefisien Korelasi dan Determinasi

CSR terhadap Agresivitas Pajak (ETR)

Model Summary

\begin{tabular}{|r|r|r|r|r|}
\hline Model & $\mathrm{R}$ & R Square & $\begin{array}{c}\text { Adjusted } \\
\text { R Square }\end{array}$ & $\begin{array}{c}\text { Std. Error } \\
\text { of the Estimate }\end{array}$ \\
\hline & $.378^{\mathrm{a}}$ & .142 & .100 & .23993 \\
\hline
\end{tabular}

a. Predictors: (Constant), CSR

b. Dependen Variable : ETR

Sumber: icmd, BEI, data diolah 
Dari tabel 5 di atas diketahui nilai $R$ sebesar 0,378 artinya korelasi (hubungan) antara CSR dengan agresivitas pajak cukup (Sarwono, 2006). Nilai $R$ square sebesar 0,142 yang berarti bahwa sebesar 14,2 \% variabel dependen yaitu agresivitas pajak dipengaruhi oleh CSR. Sedangkan sisanya (85,8 \%) dipengaruhi oleh variabel lain atau dijelaskan oleh variabel lain yang tidak dimasukkan dalam model penelitian.

Tabel 6

Hasil Uji t

CSR terhadap Agresivitas Pajak (ETR)

Coefficients $^{\mathrm{a}}$

\begin{tabular}{|c|c|c|c|c|c|}
\hline \multirow[b]{2}{*}{ MODEL } & \multicolumn{2}{|c|}{$\begin{array}{c}\text { Unstandardized } \\
\text { Coefficients }\end{array}$} & \multirow{2}{*}{$\begin{array}{c}\begin{array}{c}\text { Standardized } \\
\text { Coefficients }\end{array} \\
\text { Beta }\end{array}$} & \multirow[b]{2}{*}{$\mathrm{t}$} & \multirow[b]{2}{*}{ Sig. } \\
\hline & B & Std. Error & & & \\
\hline 1 (Constant) & .020 & .052 & & .382 & .703 \\
\hline CSR & .391 & .083 & .340 & 4.691 & .000 \\
\hline
\end{tabular}

a. Dependent Variable: ETR

Sumber : icmd, BEl, data diolah

Berdasarkan tabel 6 di atas, variabel CSR memiliki koefisien positif sebesar 0,391 dan signifikansi sebesar 0.000 (signifikansi pada alpha $5 \%$ ). Hasil $\mathrm{t}$ hitung atau $\mathrm{t}$ penelitian sebesar 4,691 lebih besar dari t tabel sebesar 1,97509. Dari angka pada tabel 6 dapat disimpulkan bahwa variabel agresivitas pajak (ETR) dipengaruhi oleh CSR dimana CSR berpengaruh positif signifikan terhadap ETR. Semakin tinggi nilai CSR maka semakin tinggi nilai ETR, dimana nilai ETR yang semakin tinggi menunjukkan tingkat agresivitas pajak yang rendah. Dengan hasil uji $t$ dan penjelasan tersebut disimpulkan bahwa CSR berpengaruh negatif signifikan terhadap agresivitas pajak.

Berdasarkan tabel di atas, persamaaan model regresi dapat dinyatakan sebagi berikut.

$$
Y=0,020+0,391 \mathrm{CSR}+\varepsilon
$$

Nilai koefisien regresi dari CSR adalah sebesar 0,391 atau sebesar 39,1 \%. Hal ini berarti setiap perubahan 1 (satu) satuan CSR akan menaikkan ETR sebesar 0,391 satuan. Dengan demikian nilai agresivitas pajak akan turun sebesar 0,391 satuan. Kesadaran perusahaan terhadap CSR akan memberikan dampak pada kesadaran kepatuhan pajak atau menurunkan perilaku penghindaran pajak atau agresivitas pajak sebesar 39,1\%.

Hasil uji koefisien determinasi (R2) antara CSR terhadap agresivitas pajak dapat dilihat pada tabel 7 di bawah ini.

Tabel 7

Uji Korelasi dan Determinasi (MRA)

Model Summary

\begin{tabular}{|l|r|r|r|r|}
\hline Model & R & R Square & \multicolumn{1}{c|}{$\begin{array}{l}\text { Adjusted } \\
\text { R Square }\end{array}$} & $\begin{array}{c}\text { Std. Error } \\
\text { of the Estimate }\end{array}$ \\
\hline 1 & $.414^{\mathrm{a}}$ & .171 & .164 & .24072 \\
\hline
\end{tabular}

a. Predictors: (Constant), CSR, CSRTI

Sumber : icmd, BEl, data diolah 
Berdasarkan tabel 7 di atas diketahui nilai $R$ sebesar 0,414 artinya korelasi (hubungan) antara CSR dan CSR*TI dengan agresivitas pajak cukup (Sarwono, 2006). Nilai $R$ square sebesar 0.171 berarti bahwa variabel independen CSR dan pemoderasi CSR dengan insentif pajak berpengaruh sebesar 17,1 \% pada agresivitas pajak, sedangkan sisanya sebesar 82,9 \% dipengaruhi oleh variabel lain yang tidak dimasukkan dalam model penelitian.

Berdasarkan hasil uji korelasi dan determinasi, variabel independen (CSR) setelah dimoderasi dengan insentif pajak (CSRTI) lebih baik dalam menjelaskan variabel dependen (agesivitas pajak) dibanding dengan sebelum dimoderasi. Hal ini bisa dilihat dari nilai $R$ square pada tabel 7 sebesar 0,171 atau 17,1\% lebih besar dari nilai $R$ square pada tabel 5 yaitu sebesar 0,142 atau 14,2\%. Hasil ini dapat menggambarkan bahwa insentif pajak sebagai variabel moderating yang dimasukkan ke dalam model regresi memperkuat hubungan antara variabel CSR dan variabel agresivitas pajak (ETR).

Tabel8

Hasil Uji t - CSR terhadap Agresivits Pajak (ETR) - MRA

Coefficients $^{a}$

\begin{tabular}{|c|c|c|c|c|c|c|}
\hline & \multirow[b]{2}{*}{ Model } & \multicolumn{2}{|c|}{$\begin{array}{l}\text { Unstandardized } \\
\text { Coefficients }\end{array}$} & \multirow{2}{*}{$\begin{array}{c}\text { Standardized } \\
\text { Coefficients }\end{array}$} & \multirow[b]{2}{*}{$T$} & \multirow[b]{2}{*}{ Sig. } \\
\hline & & $\mathrm{B}$ & Std. Error & & & \\
\hline \multirow[t]{3}{*}{1} & (Constant) & .111 & .037 & & 3.031 & .003 \\
\hline & CSR & .340 & .212 & 296 & 3.602 & .000 \\
\hline & $\mathrm{CSR}^{*} \mathrm{TI}$ & .277 & .063 & .323 & 4.421 & .000 \\
\hline
\end{tabular}

Dependent Variable: ETR

Berdasarkan tabel 8 di atas, variabel CSR memiliki koefisien positif sebesar 0,340 dan signifikansi sebesar 0,000 (signifikansi pada alpha 5\%). Hasil $t$ hitung atau $t$ penelitian sebesar 3,602 lebih besar dari t tabel sebesar 1,97509. Dari angka pada tabel 8 dapat disimpulkan bahwa variabel agresivitas pajak (ETR) dipengaruhi oleh CSR dimana CSR berpengaruh positif signifikan terhadap ETR. Semakin tinggi nilai CSR maka semakin tinggi nilai ETR, dimana nilai ETR yang semakin tinggi menunjukkan tingkat agresivitas pajak yang rendah. Dengan hasil uji $t$ dan penjelasan tersebut disimpulkan bahwa CSR berpengaruh negatif signifikan terhadap agresivitas pajak.

Berdasarkan tabel di atas, persamaaan model regresi dapat dinyatakan sebagai berikut:

$$
Y=0.111+0,340 \mathrm{CSR}+0.277 \mathrm{CSR} * \mathrm{TI}+\varepsilon
$$

Interaksi antara CSR dan insentif pajak (TI) memiliki koefisien sebesar 0,277 dan siginifikansi sebesar 0,000. Hasil t hitung 4,421 lebih besar dari t tabel sebesar 1,97519. Dari angka tersebut menujukkan bahwa variabel moderating (insentif pajak) bepengaruh dalam memperkuat hubungan antara CSR dengan agresivitas pajak. Kesadaran perusahaan terhadap CSR akan berdampak pada kesadaran kepatuhan pajak atau menurunkan perilaku penghindaran pajak atau agresivitas pajak sebesar $27,7 \%$. Insentif pajak berupa tax deduction (pengurangan pajak) atas beban CSR akan meningkatkan kesadaran melakukan pembayaran dan pengungkapan CSR serta tidak melakukan tindakan merekayasa pembebanan CSR pada pos lainnya (yang merupakan tindakan illegal tax avoidance).

Tabel 9

Uji Korelasi dan Determinasi

CSR terhadap Agresivitas Pajak dengan Variabel Kontrol 
Model Summary

\begin{tabular}{|l|r|r|r|r|}
\hline Model & $\mathrm{R}$ & R Square & \multicolumn{1}{c|}{$\begin{array}{l}\text { Adjusted } \\
\text { R Square }\end{array}$} & \multicolumn{1}{c|}{$\begin{array}{c}\text { Std. Error } \\
\text { of the Estimate }\end{array}$} \\
\hline 1 & $.438^{\mathrm{a}}$ & .192 & .180 & .24242 \\
\hline
\end{tabular}

a. Predictors: (Constant), CSR, CSRTI, DER, SIZE, ROA, Cap-Int, Inv-Int

Sumber : icmd, BEI, data diolah

Dari tabel 9 di atas diketahui nilai $R$ sebesar 0,438 artinya korelasi (hubungan) antara CSR dan CSR*TI dengan agresivitas pajak cukup (Sarwono, 2006). Nilai $R$ square sebesar 0,192 berarti bahwa pengaruh variabel independen CSR dan pemoderasi CSR*TI serta variabel kontrol DER, Size, ROA, Cap-Int dan Inv-Int sebesar 19,2 \% terhadap agresivitas pajak, sedangkan sisanya sebesar 80,80\% dipengaruhi oleh variabel lain yang tidak dimasukkan dalam model penelitian.

\section{Tabel 10 \\ Hasil Uji F \\ ANOVA $^{\mathrm{a}}$}

\begin{tabular}{|c|c|c|c|c|c|c|}
\hline & Model & Sum of squares & $d f$ & Mean Square & $\mathrm{F}$ & Sig. \\
\hline \multirow[t]{3}{*}{1} & Regression & 1.231 & 6 & .205 & 3.492 & $.003^{b}$ \\
\hline & Residual & 9.579 & 163 & .059 & & \\
\hline & Total & 10.810 & 169 & & & \\
\hline
\end{tabular}

a. Dependent Variable: ETR

b. Predictors: (Constant), CSR, CSRTI, DER, SIZE, ROA, Cap-Int, Inv-Int Sumber : icmd, BEl, data diolah

Hasil penelitian sesuai tabel 10 menunjukkan nilai $F$ hitung sebesar 3,492 (lebih besar dari $\mathrm{F}$ tabel 2,15) dengan tingkat signifikansi sebesar 0,003 (lebih kecil dari tingkat signifikansi 0,05), maka dapat disimpulkan bahwa secara bersama-sama (simultan) CSR, CSR*TI, Leverage (DER), Size,
ROA, Cap-Int dan Inv-Int mempunyai pengaruh positif dan signifikan terhadap agresivitas pajak. Dengan demikian secara simultan variabel-variabel tersebut mampu memprediksi atau menjelaskan agresivitas pajak, sehingga model yang digunakan dalam penelitian ini telah layak (fit).

Tabel 11

Hasil Uji t

Coefficients $^{a}$

\begin{tabular}{|c|c|c|c|c|c|}
\hline \multirow[b]{2}{*}{ Model } & \multicolumn{2}{|c|}{$\begin{array}{c}\text { Unstandardized } \\
\text { Coefficients }\end{array}$} & \multirow{2}{*}{$\begin{array}{c}\begin{array}{c}\text { Standardized } \\
\text { Coefficients }\end{array} \\
\text { Beta }\end{array}$} & \multirow[b]{2}{*}{$t$} & \multirow[b]{2}{*}{ Sig. } \\
\hline & B & Std. Error & & & \\
\hline 1 (Constant) & .096 & .941 & & .528 & .599 \\
\hline CSR & .437 & .083 & .342 & 2.904 & .000 \\
\hline CSRTI & .272 & .068 & .316 & 3.993 & .000 \\
\hline DER & .056 & .058 & .076 & .967 & .335 \\
\hline SIZE & .079 & .133 & .053 & .653 & .515 \\
\hline ROA & .046 & .150 & .047 & 2.610 & .043 \\
\hline
\end{tabular}




\begin{tabular}{|l|r|r|r|r|r|}
\hline CAP-INT & .068 & .098 & .053 & 3.462 & .045 \\
INV-INT & .074 & .215 & .028 & .346 & .729 \\
\hline
\end{tabular}

a. Dependent Variable: ETR

Berdasarkan tabel 11 di atas, variabel CSR memiliki t hitung sebesar 2,904. Nilai ini lebih besar dari t tabel $(2,904>1,97509)$, sedangkan hasil probabilitasnya lebih kecil dari tingkat signifikansi $(0,000<0,05)$. Dari angka tersebut dapat disimpulkan bahwa variabel agresivitas pajak (ETR) dipengaruhi oleh CSR dimana CSR berpengaruh positif signifikan terhadap ETR. Semakin tinggi nilai CSR maka semakin tinggi nilai ETR, dimana nilai ETR yang semakin tinggi menunjukkan tingkat agresivitas pajak yang rendah. Dengan hasil uji $t$ dan penjelasan tersebut disimpulkan bahwa CSR berpengaruh negatif signifikan terhadap agresivitas pajak.

Hasil uji $t$ untuk variabel kontrol Leverage (DER) menunjukkan nilai $(0,967<1,97529)$ dengan signifikansi $(0,335>0,05)$ sehingga Leverage (DER) tidak berpengaruh signifikan terhadap agresivitas pajak. Hasil uji t Size menunjukkan nilai $(0.653<1,97539) \quad$ dengan signifikansi $(0,515>0,05)$ sehingga size tidak berpengaruh signifikan terhadap Agresivitas Pajak. Hasil uji t ROA menunjukkan nilai $(2,610>1,975349)$ dengan signifikansi $(0,043<0,05)$ maka ROA mempunyai pengaruh yang signifikan terhadap agresivitas pajak. Hasil uji $t$ Cap-Int menunjukkan $(3,462>1,97559)$ dengan signifikansi $(0,045<0,05)$ yang berarti Cap-Int mempunyai pengaruh yang signifikan terhadap agresivitas pajak. Hasil uji $t$ Inv-Int menunjukkan nilai $(0,282<1,97569)$ dengan signifikansi $(0,729>0,05)$ berarti Inv-Int tidak berpengaruh signifikan terhadap agresivitas pajak.

Berdasarkan tabel di atas, persamaaan model regresi dapat dinyatakan sebagai berikut.

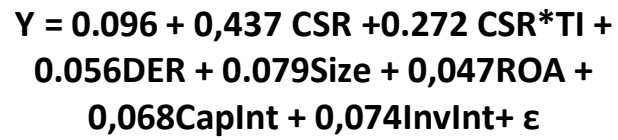

Nilai koefisien regresi dari CSR adalah sebesar 0,437 atau sebesar 43,7 \%. Hal ini berarti setiap perubahan 1 (satu) satuan CSR akan menaikkan ETR sebesar 0,437 satuan. Dengan demikian nilai agresivitas pajak akan turun sebesar 0,437 satuan. Kesadaran perusahaan terhadap CSR akan memberikan berdampak pada kesadaran kepatuhan pajak atau menurunkan perilaku penghindaran pajak atau agresivitas pajak sebesar $43,7 \%$.

Nilai koefisien regresi dari interaksi $\mathrm{CSR}^{*} \mathrm{TI}$ adalah sebesar 0,272 atau sebesar 27,2 $\%$. Hal ini berarti apabila nila koefisien regresi CSR tetap (tidak berubah), maka perubahan 1 (satu) satuan insentif pajak (TI) atas CSR akan menaikkan ETR sebesar 0,27 satuan. Dengan demikian nilai agresivitas pajak akan turun sebesar 0,27 satuan. Insentif pajak berupa tax deduction (pengurangan pajak) atas beban CSR akan meningkatkan kesadaran melakukan pembayaran dan pengungkapan CSR serta tidak melakukan tindakan merekayasa pembebanan CSR pada pos lainnya (yang merupakan tindakan illegal tax avoidance). Dengan demikian insentif pajak memperkuat hubungan CSR dan agresivitas pajak.

Nilai koefisien regresi dari DER adalah sebesar 0,056 atau sebesar 5,6 \%. Hal ini berarti setiap perubahan 1 (satu) satuan CSR akan menaikkan ETR sebesar 0,056 satuan. Dengan demikian nilai agresivitas pajak akan turun sebesar 0,056 satuan. Nilai koefisien regresi dari Size adalah sebesar 0,079 atau sebesar 7,9\%. Hal ini berarti setiap perubahan 1 (satu) satuan CSR akan menaikkan ETR sebesar 0,079 satuan. Dengan demikian nilai agresivitas pajak akan turun sebesar 0,079 satuan.

Nilai koefisien regresi dari ROA adalah sebesar 0,047 atau sebesar 4,7 \%. Hal ini berarti setiap perubahan 1 (satu) satuan CSR akan menaikkan ETR sebesar 0,047 satuan. Dengan demikian nilai agresivitas pajak akan turun sebesar 0,047 satuan. Nilai koefisien regresi dari Cap-Int adalah sebesar 0,068 atau 
sebesar 6,8 \%. Hal ini berarti setiap perubahan 1 (satu) satuan CSR akan menaikkan ETR sebesar 0,068 satuan. Dengan demikian nilai agresivitas pajak akan turun sebesar 0,068 satuan. Sedangkan Nilai koefisien regresi dari Inv-Int adalah sebesar 0,074 atau sebesar 7,4 \%. Hal ini berarti setiap perubahan 1 (satu) satuan CSR akan menaikkan ETR sebesar 0,074 satuan. Dengan demikian nilai agresivitas pajak akan turun sebesar 0,074 satuan.

\section{Pembahasan}

\section{Pengaruh CSR terhadap Agresivitas Pajak.}

Hasil pengujian hipotesis pertama (H1) dari uji t baik dari model (persamaan) regresi 1, 2 atau 3 menunjukkan bahwa pengungkapan CSR berpengaruh positif signifikan terhadap ETR. Dimana ETR yang tinggi menunjukkan agresivitas pajak yang rendah. Semakin tinggi nilai CSR maka semakin tinggi nilai ETR dimana nilai ETR yang semakin tinggi menunjukkan tingkat agresivitas pajak yang rendah. Hasil ini menjelaskan bahwa semakin tinggi perusahaan melakukan aktivitas CSR, maka semakin tinggi sikap tanggung jawab yang dimilikinya dalam melaksanakan kewajiban pajaknya. Dengan demikian semakin tinggi CSR perusahaan maka semakin rendah agresivitas pajaknya.

CSR adalah bentuk akuntabilitas kepada masyarakat (lingkungan, pelanggan, karyawan, pemasok dan masyarakat lainnya). Kepatuhan pajak (tax compliance) merupakan bentuk akuntabilitas wajib pajak kepada pemerintah. CSR dan kepatuhan pajak mempunyai korelasi positif. Dengan demikian CSR berbanding terbalik dengan penghindaran pajak atau agresivitas pajak. Perusahaan yang aktif dalam program CSR cenderung tidak terlibat dalan agresivitas pajak (Avi-Yonah, 2006).

Hasil pengujian hipotesis dengan model regresi 3, yaitu penggunaan variabel kontrol diperoleh hasil bahwa profitabilitas atau return on assets (ROA) dan capital intensity (Cap-Int) berpengaruh positif signifikan terhadap ETR. Dengan demikian ROA dan capital intensity mampu mengontrol pengaruh CSR terhadap agresivitas pajak.

Profitabilitas (ROA) adalah kemampuan perusahaan menghasilkan keuntungan dari aktivitas bisnisnya. Dengan demikian, kenaikan ROA akan mengakibatkan kenaikan ETR, sehingga ROAmemiliki pengaruh yang positif dengan ETR atau pengaruh negatif terhadap agresivitas pajak (Ardyansyah dan Zulaikha, 2014). Apabila ROA (profitabilitas) mengalami peningkatan, maka penghindaran pajak akan mengalami penurunan.

Sementara itu, capital intensity (Cap-Int) berpengaruh positif signifikan terhadap ETR atau pengaruh negatif terhadap agresivitas pajak. Capital intensity ini terkait investasi perusahaan dalam aset tetap. Menurut Ratmono (2015), penguruh tersebut didasarkan pada keterkaitan antara besar kecilnya aset tetap dengan besar kecilnya perusahaan. Semakin besar perusahaan cenderung mempunyai aset tetap yang tinggi dan hasil usaha yang efisien. Walaupun perusahaan mempunyai beban penyusutan yang tinggi, tetapi perusahaan yang besar mempunyai manajemen yang baik, sehingga mampu menghasilkan revenue yang tinggi. Dengan demikian, perusahaan mampu memperoleh laba sebelum pajak dan ETR yang tinggi.

Hasil pengujian tersebut menunjukkan dukungan terhadap hipotesis penelitian, dimana (pengungkapan) CSR berpengaruh negatif signifikan terhadap agresivitas pajak. Hasil penelitian ini sejalan dengan Dwi Ratmono, Winarti Monica Sagala (2015) dan Lanis dan Richardson (2012) yang menyatakan bahwa semakin tinggi CSR semakin rendah agresivitas pajak. Hasil penelitian ini berbeda dengan penelitian Dudi Wahyudi (2015) yang menyatakan bahwa CSR tidak berpengaruh signifikan terhadap tindakan penghindaran pajak perusahaan.

\section{Pengaruh Insentif Pajak terhadap Hubungan CSR dengan Agresivitas Pajak.}

Hasil pengujian hipotesis kedua $(\mathrm{H} 2)$ dengan moderated regression analysis (MRA) menunjukkan bahwa insentif pajak berpengaruh positif dan signifikan terhadap hubungan antara CSR dengan agresivitas pajak. Dengan kata lain, semakin tinggi pengungkapan CSR maka semakin rendah 
agresivitas pajak, terutama pada saat perusahaan memanfaatkan insentif pajak yang diberikan oleh pemerintah berupa tax deduction atas CSR.

Sebagaimana diketahui bahwa CSR dan pajak adalah cost of doing business. Dengan demikian, perusahaan akan berusaha merencanakan CSR dan pajak seefisien mungkin dan dimungkinkan memilih salah satu dari keduanya. Dengan adanya insentif pajak tersebut, maka perusahaan akan memperoleh pengurangan beban, yaitu beban pajak. Insentif pengurangan pajak tersebut akan mendorong lebih banyak lagi dukungan bagi kegiatan pendidikan, penelitian dan pengembangan, pengembangan infrastruktur sosial dan lainnya.

Insentif pajak atas CSR juga dapat menghindarkan perusahaan untuk menyiasati biaya CSR agar dapat dikurangkan dari penghasilan bruto dengan cara melaporakan pada biaya lainnya (Amna, 2010). Misalnya sebelum berlakunya ketentuan pasal 6 ayat 1 UU PPh jo PP 93 tahun 2010; sumbangan untuk olah raga, pemberdayaan ekonomi masyarakat sekitar lokasi tambang dan sumbangan bencana alam dimasukkan dalam biaya promosi agar dapat dikurangkan dari penghasilan bruto. Secara fiskal, perlakuan biaya seperti ini adalah tindakan penghindaran pajak yang tidak diperkenankan (unacceptable tax avoidance).

Hasil studi yang dilakukan PIRAC mempunyai korelasi dengan hasil penelitian ini. Hasil studi empiris ini menyatakan bahwa semakin tinggi pengungkapan CSR maka semakin rendah agresivitas pajak, terutama pada saat perusahaan memanfaatkan insentif pajak atas CSR. Sementara itu, hasil studi PIRAC mengkonfirmasikan bahwa insentif pajak berupa tax deduction atas beban CSR telah meningkatkan kesadaran perusahaan untuk mengeluarkan beban CSR. Dengan demikian semakin meningkatnya kesadaran membayar CSR (setelah diberikan insentif pajak), maka agresivitas pajak akan turun. Dengan demikian terdapat kesesuaian antara hasil penelitian ini dengan studi yang dilakukan PIRAC.
Hasil pengujian yang menyatakan insentif pajak berpengaruh positif dan signifikan terhadap hubungan antara CSR dengan agresivitas pajak; dimana semakin tinggi pengungkapan CSR maka semakin rendah agresivitas pajak, terutama pada saat perusahaan memanfaatkan insentif pajak yang diberikan oleh pemerintah berupa tax deduction atas CSR menunjukkan dukungan terhadap hipotesis penelitian. Yaitu insentif pajak berpengaruh positif signifikan terhadap hubungan CSR dengan agresivitas pajak. Hasil penelitian ini sejalan dengan penelitian Amna (2010) dan teori pertukaran sosial. Insentif pajak berupa tax deduction memberikan benefit bagi perusahaan. Konsekuensi benefit tersebut, perusahaan akan melakukan tindakan timbal balik dengan tidak melakukan penghindaran pajak (agresivitas pajak).

\section{SIMPULAN, KETERBATASAN DAN IMPLIKASI HASIL PENELITIAN}

Hasil pengujian pengaruh CSR terhadap agresivitas pajak membuktikan CSR berpengaruh positif siginifikan terhadap ETR. Semakin tinggi nilai CSR maka semakin tinggi nilai ETR, dimana nilai ETR yang tinggi menunjukkan tingkat agresivitas pajak yang rendah. Dengan demikian disimpulkan bahwa semakin tinggi CSR semakin rendah agresivitas pajak. CSR berpengaruh negatif terhadap agresivitas pajak. Hasil pengujian pengaruh insentif pajak terhadap hubungan CSR dengan agresivitas pajak. Insentif pajak dimaksud adalah tax deduction; dengan menggunakan MRA, insentif pajak sebagai variable moderating memperkuat hubungan antara CSR dengan agresivitas pajak. Semakin tinggi pengungkapan CSR maka semakin rendah agresivitas pajak, terutama pada saat perusahaan memanfaatkan insentif pajak yang diberikan oleh pemerintah berupa tax deduction atas CSR. Dengan insentif pajak atas beban CSR, maka perusahaan akan memperoleh tax saving (penghematan pajak). Sesuai teori pertukaran sosial, perusahaan yang memperoleh benefit dari pemerintah, maka akan melakukan tindakan timbal balik, 
yaitu akan meningkatkan kepatuhan pajak atau tidak melakukan agresivitas pajak.

Keterbatasan penelitian meliputi 1) Sampel perusahaan di sektor pertambangan, sehingga kesimpulan di atas pada prinsipnya berlaku untuk sektor tersebut. 2) Periode pengamatan penelitian selama 5 tahun yakni mulai dari tahun 2011 sampai dengan 2015 sehingga hasil penelitian tidak dapat digeneralisasi untuk periode yang lebih panjang. Apabila periode penelitian diperluas, maka kemungkinan hasil penelitian kausal antara CSR dengan agresivitas pajak menunjukkan korelasi dan determinasi yang lebih kuat. 3) Penggunaan variabel kontrol (akuntansi) yang hanya diwakili oleh lima variabel yaitu ukuran perusahaan (size), leverage, return on assets, capital intensity, dan inventory intensity. Sesuai kesimpulan korelasi dan determinasi hasil penelitian ini, terdapat variabel (akuntansi) lainnya yang memberikan pengaruh terhadap agresivitas pajak. Dengan demikian, apabila variabel lain digunakan dalam penelitian, maka kemungkinan akan meningkatkan korelasi dan determinasi antara CSR dengan agresivitas pajak.

Saran yang digunakan bagi pihak yang ingin melanjutkan penelitian ini adalah; 1) menggunakan variabel-variabel independen lain, seperti ukuran dewan komisaris, karakter eksekutif, kepemilikan institusional, koneksi politik dan corporate governance yang patut diduga berpengaruh terhadap agresivitas pajak 2) dapat menggunakan sampel penelitian pada perusahaan sektor non-tambang. Hal ini untuk memberikan gambaran lain tentang luasnya pengungkapan CSR dan pengaruhnya terhadap agresivitas pajak Dan 3) dapat menggunakan proksi lain dari agresivitas pajak seperti book tax difference (BTD).

Bagi emiten sektor pertambangan, penelitian ini dapat dijadikan sebagai masukan dalam merancang program CSR, perusahaan hendaklah memperhatikan seluruh pemangku kepentingan (stakeholders), yaitu pemilik, pegawai, pemasok, pembeli, masyarakat, kompetitor, media, pemerhati lingkungan dan pemerintah. Hal ini selain sebagai tuntutan etis, juga diharapkan agar mendatangkan manfaat ekonomis dan menjaga kelangsungan bisnis perusahaan. Di samping program CSR dirancang dengan memperhitungkan nilai bisnis (business value), program CSR juga harus dirancang dengan mempertimbangkan ketentuan pajak. Sehingga perusahaan akan memperoleh keuntungan (tax benefit) dari insentif pajak yang diberikan pemerintah. Untuk itu perusahaan dituntut untuk memahami ketentuan peraturan perpajakan terkait CSR sesuai pasal 6 UU PPh jo PP 93 tahun 2010.

\section{DAFTAR PUSTAKA}

Alvarez, Lorenzo, dan Garcia-Sanchez, 2011. CSR and Inovation: A Resource Based Theory, Management Discusion, Vol. 49 No.10, 1709-1727.

Amna, Afiyah, 2010. Analisis UU PPh dan Peraturan Perpajakan Terkait Insentif Pajak dan Pencegahan Tax avoidance Atas Kegiatan Tanggung Jawab Sosial Perusahaan, Tesis Magister Akuntansi UI. Ardyansyah, Danis., Zulaikha. 2014. Pengaruh Size, Leverage, Profitability, Capital Intensity Ratio dan Komisaris Independen Terhadap Effective Tax Rate (Etr). Semarang: Fakultas Ekonomika dan Bisnis Universitas Diponegoro.

Badan Pengawas Pasar Modal, 2006. Kep. No 134/BL/2006 Tentang Kewajiban Penyampaian Laporan Tahunan bagi Emiten atau Perusahaan Publik.

Blaylock, Shevlin, dan Wilson, 2012. Tax Avoidance, Large Positive Temporary BTD, and Earning Persistence, The Accouting Review, vol87, No.1, 91-120.

Brojonegoro, Bambang, 2016. Hindari Pajak: 2000 PMA dibidik BKPM. https://pemeriksaanpajak.com/2016/03 /29/hindari-pajak-2-000-pma-dibidikbkpm, 29 Maret 2016 (10:16).

Budiman, Judi., Setiyono. 2012. Pengaruh Karakter Eksekutif terhadap Penghindaran Pajak (Tax Avoidance). Fakultas Ekonomi. Universitas Islam Sultan Agung.

Chang, Hsiao, dan Tsai, 2013. Earnings,

JIAFE (Jurnal Ilmiah Akuntansi Fakultas Ekonomi)

Volume 2 No. 2 Tahun 2016, Hal. 39-58 
Institutional Investors, Tax avoidance, and Firm Value: Evidence from Taiwan, Journal of International Accounting, Auditing and Taxation, 98-108.

Chen ,Shuping, Chen Xia, Qian Cheng \& Selvin, Terry, 2008, Are Family Firms More Tax Aggressive Than Non Family Firms?, Journal of Financial Economics, 95, 4146.

Darussalam, 2009. "Tax Avoidance, Tax Planning, Tax Evasion, dan Anti Avoidance Rule. "Observasion \& Research of Taxation" http://www.ortax.org/ortax/?mod=issue \&page=show $\& \mathrm{id}=36 \& \mathrm{q}=\& \mathrm{~h} / \mathrm{m}=1, \quad 21$ Maret 2016 (10:10).

David dan Gallego, 2009. The Interrelationship Between Corporate Income Tax and CSR, Journal of Applied Accounting Research, Vol. 10 No.3, 208-223.

Dedi Diah Cahyono, Rita Andini, Kharis Raharjo, 2016. Pengaruh Komite Audit, Kepemilikan Institusional, Dewan Komisaris, Ukuran Perusahaan (Size), Leverage (DER) dan Profitabilitas (ROA) Terhadap Tindakan Penghindaran Pajak (Tax Avoidance) pada perusahaan yang listing BEI pada periode 2011-12013, Journal of Accounting, Vol. 2 No. 2

Esa dan Ghazali, 2010. CSR dan CG in Malaysian Government-linked Companies, Corprate Governance, Vol.12 no.3.

Frank, Lynch, Rego, 2009. Tax Reporting Aggressiveness and Its Relation to Aggressive Financial Reporting, The Accounting Review, Vol. 84, No.2, 467496.

Freeman, R. Edward (1984), 2015. A Survey of Sustainability Reporting Practices of Australian Reporting Entities, Australian Accounting Review, Vol.15 no.1.

Frost, Jones, Loftus, Laan, 2005. A Survey of Sustainability Reporting Practices of Australian Reporting Entities, Australian Accounting Review, Vol.15 no.1.

Gamerschlag, Moller, Verbeeten, 2011. Determinants of Voluntary CSR Disclosure: Empirical Evidence From Germany, Rev Manag Sci, 5:233-262.
Gay, L.R. dan Diehl, P.L. (1992), Research Methods for Business and Management, MacMillan Publishing Company, New York.

Ghozali, Imam, 2013. Aplikasi Analisis Multivariat dengan Program IBM SPSS 21. Edisi 7, Penerbit Universitas Diponegoro, Semarang.

Hanlon dan Heitzman, 2010. A Review of Tax Research, Journal of Accounting and Economics, 50, 127-178.

Hanlon dan Slemrod, 2009. What Does Tax Agresiveness Signal? Evidence to News About Tax Shelter Involvement. Journal of Public Economics, 93: 126-141.

Hardianti, Eka Puji, 2014, Analisis Tindakan Penghindaran Pajak Pada Perusahaan Yang Mempunyai Koneksi Politik (Studi pada Perusahaan BUMN yang terdaftar di Bursa Efek Indonesia periode 20102013). http://www.ejurnal.com/2015/07/analisis-tindakanpenghindaran-pajak.html.

Hidayanti, Alfiyani Nur \& Herry Laksito.(2013). Pengaruh Aantara Kepemilikan Keluarga dan Corporate Governance Terhadap Tindakan Pajak Agresif. Diponegoro Journal of Accounting, 2(2): 1-12.

Hong Yongtao \& Andersen Margareth, 2011. The Relationship Between CSR and Earning Management: An Explanatory Study, Journal Business Ethic, 104:461471.

Huseynov, Klamm, 2012. Tax Avoidance, Tax Management, and Corporate social responsibility, Journal of Corporate Finance, 18. 804-827.

Hutagaol, John, http://economy.okezone.com/read/201 6/03/02/20/1326165/ditjen-pajakungkap-penyebab-tax-ratio-ri-hanya-10, 06-12-2016 (08:44).

Ikatan Akuntansi Indonesia, 2009. Standar Akuntansi Keuangan, Jakarta: Salemba Empat.

Khurana, Inder K. dan Moser, William J., 2009. Institusional Ownership and Tax Agressiveness. www.ssrn.com, $30 \mathrm{Juli}$ 2016 (20:22). 
Lanis, Roman and Richardson, Grant 2012. Corporate Social Responsibility and Tax Aggressiveess: An Empirical Analysis,/ J. Account, Public Policy, 31, 86-108.

Lanis, Roman and Richardson, Grant, 2013.Corporate Social Responsibility and Tax Agresiveness: A Test of Legitimacy Theory, Accounting, Auditing, \& Accountability Journal, Vol.26, No.1, 75100.

Mangoting, Yenni 1999. Tax Planning : Sebuah Pengantar Sebagai Alternatif Meminimalkan Pajak. Jurnal Akuntansi dan Keuangan. Vol.1; No. 1, Hal. 43-53.

Mardiasmo, 2003. Perpajakan, Edisi Revisi. Andi Offset, Yogyakarta.

Muid Dul, 2011. Pengaruh CSR terhadap Stock Return, Fokus Ekonomi, Vol.6 no.1.

Negoro, Haryo Abduh, 2013. SDM Yang Berkarakter Menyongsong DJP Gemilang Pajak Kemimpinan dan Masa Depan Lintas Generasi. DJP Kanwil Jawa Tengah I Tahun 2013.

Pradipta dan Purwaningsih, 2011. Pengaruh Luas Pengungkapan Tanggung Jawab Sosial dan Lingkungan Perusahaan Terhadap Earning Response Coeficient (ERC), Dengan Ukuran Perusahaan dan Leverage Sebagai Variabel Kendali, Simposium Nasional Akuntansi 2011.

Prastowo, Yustinus, 2016. Apa Perbedaan Praktik Penghindaran Pajak dan Penggelapan Pajak, http://bisniskeuangan, kompas.com/read/2016/04/14/0830008 26/, 12-11-2016 (12:30).

Preuss, Lutz, 2010. Tax avoidance and Corporate Social Responsibility: You Can't Do Both Or Can You?, Corporate Governance, Vol.10 No.4.

Ratmono Dwi, Sagala Winarti Monika, 2015. Pengungkapan Corporate Social Responsibility (CSR) sebagai sarana legitimasi: Dampak terhadap Tingkat Agresivitas Pajak. Jurnal Nominal / Volume 2/ 2015.

Republik Indonesia, 2007.UU No.25 tahun 2007 Tentang Penanaman Modal Republik Indonesia, 2007.UU No.40 Tahun 2007
Tentang Perseroan Terbatas Republik Indonesia, 2008. UU No.36 tahun 2008 Tentang Pajak Penghasilan.

Riswari, DyahArdana., dan Cahyonowati, Nur. 2012. Pengaruh Pengungkapan Corporate Social Responsibility terhadap Nilai Perusahaan dengan Corporate Governance sebagai Variabel Moderating: Studi pada Perusahaan Publik Non Finansial yang Tercatat di Bursa Efek Indonesia. Diponegoro Journal of Accounting. Vol.1, No.1 : 1-12.

Rodriguez, Elena Fernandez and Arias, Antonio Martinez, 2014 "Determinants of The ETR in The BRIC Countries". http:/ressearchgate.net, 09-01-2017 (09:41).

Saputra, Eko, 2015. Membunuh indonesia. net/.../kejahatan-keuangan-di-sektorpertamb..., 30-12-2016 (08:30).

Sawir, Agnes, 2009. Analisa Kinerja Keuangan dan Perencanaan Keuangan Perusahaan, PT. Gramedia Pustaka Utama, Jakarta.

Sikka, Prem, 2010. Smoke and Mirrors: CSR and Tax avoidance, Accounting Forum, 153168.

Thibaut, John dan Kelley, Harold, 1959. The Social Psycology of Groups, Chapman and Hall., Ltd, London.

Tongkachok dan Chaikeaw, 2012. CSR: The Emperical Study of Listed Companies in the Stock Exchange of Thailand, International Journal of Business and Social Science, Vol.3 No.21.

Wahyudi, Dudi, 2015. Analisis Empiris Pengaruh CSR Terhadap Penghindaran Pajak. Jurnal Lingkar Widyaswara 2 (4): 13-15.

Watson, Luke, 2011. "Corporate Social Responsibility and Tax Aggressiveness: An Examination of Unrecognized Tax Benefits". Social Science Research Network.

Watson, Luke, 2012. "Corporate Aggressiveness: An Examination of Unrecognized Tax Benefits. Pensylvania: The Pensylvania State University.

Winata, Fenny 2012. "Pengaruh Corporate Governance terhadap Tax Avoidance

JIAFE (Jurnal Ilmiah Akuntansi Fakultas Ekonomi)

Volume 2 No. 2 Tahun 2016, Hal. 39-58 
Pada Perusahaan yang Terdaftar di Bursa Efek Indonesia Tahun 2013". Tax Accounting Review, Vol. 4 No. 1.

Winarsih, Rina, Prasetyono dan Kusufi, M. Syam. 2014. "Pengaruh Good Corporate Goverment dan Corporate Social Responsibility Terhadap Tindakan Pajak Agresif." Simposium Nasional Akuntansi XVII.Mataram www.global reporting.org (15 September 2016, 16:40) http:// www.pirac. Org /2012/05/22/ sumbangan-sosial-perusahaan/ (07-112017, 16:00).

Wijaya, Ibnu. 2014. Mengenal Penghindaran
Pajak (Tax Avoidance). http ://www.pajak.go.id/content/article/men genal-penghindaran-pajak-tax avoidance (11-01-2017, 13:11).

Yoehana, Maretta. 2013. Analisis Pengaruh Corporate Social Responsibility Terhadap Agresivitas Pajak.Fakultas Ekonomika dan Bisnis Universitas Diponegoro. Semarang.

Yonah, Avi, 2006. Corporate Social Responsibility and Strategic Tax Behaviour, Tax and Corporate Governance. 